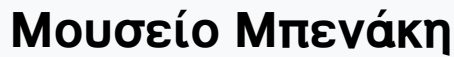

Tóp. 1, Ap. 11-12 (2012)

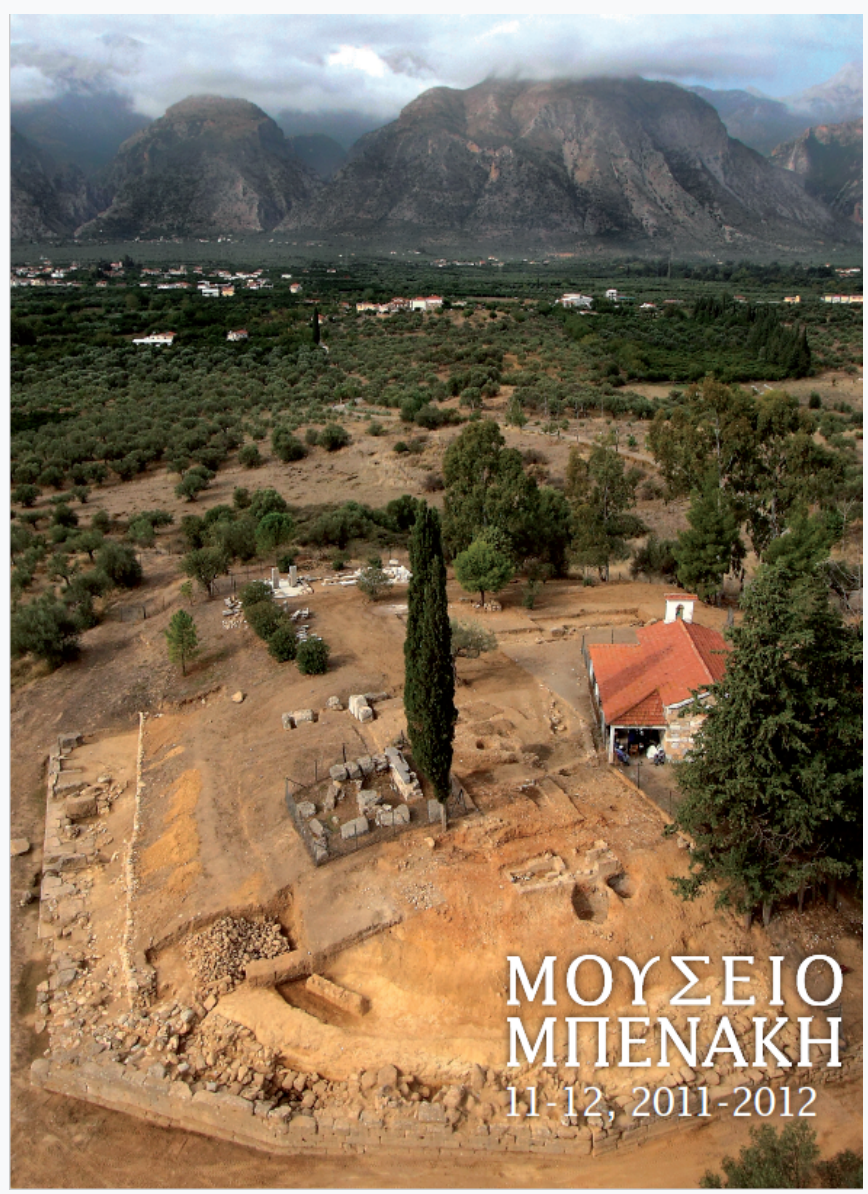

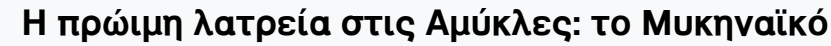
Iعpó

Katie Demakopoulou

doi: $10.12681 /$ benaki.17773

Copyright $\odot$ 2018, Katie Demakopoulou

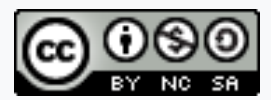

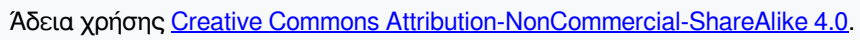

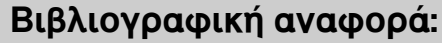

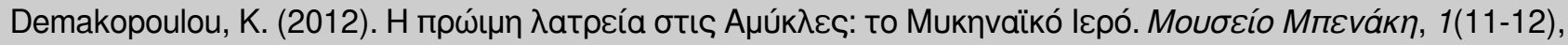
105-112. https://doi.org/10.12681/benaki.17773 


\section{The Early Cult at the Amyklaion The Mycenaean Sanctuary}

At Amyklae, on the hill of Agia Kyriaki, the location of the well known Archaic Apollo sanctuary, an earlier cult has been attested. Since the late 13th century $\mathrm{BC}$ there was at this site one of the most significant sanctuaries of Mycenaean Greece that was in use for almost two centuries. The excavations conducted by Christos Tsountas in $1890^{1}$ and later by German archaeologists ${ }^{2}$ brought to light a large number of terracotta human and animal figures and figurines, which firmly established the existence of a Mycenaean sanctuary on the hill. This material has been increased with more terracottas from the recent excavations, a project of the Benaki Museum under Prof. A. Delivorrias and Dr S. Vlizos.

Although a large Early and Middle Helladic Bronze Age settlement was located on the southeast slopes of the hill, there are no buildings associated with Mycenaean pottery. The pottery itself is not plentiful and was recovered from disturbed deposits both in the old and recent excavations. From the Mycenaean sanctuary, which seems to have been isolated on the hill, no structural remains have been preserved. Ritual activity is attested only by the abundance of the clay figures and figurines found at the site. ${ }^{3}$

The Mycenaean finds were discovered with Protogeometric and Geometric pottery in unstratified deposits and were scattered in a large area. ${ }^{4}$ They are all of clay, mostly terracottas and some fragmentary pottery. From the old excavations there are about 150 figures and figurines in total, most of them fragmentary. ${ }^{5}$ A few, however, are intact or almost so. They comprise two fragments of exceptionally large terracotta human figures (as distinct from figurines), 74 handmade Psi-type figurines, two figurines of horse riders, four bird figurines, 35 small handmade animal figurines and 33 large wheelmade animal figures, which were probably intended to be bovids or bulls. From the recent excavations come some more fragments of handmade human and animal figurines, as well as parts of wheelmade animal figures.

Of the entire group most important are the two fragments of large wheelmade figures: one is the upper part of the head of an almost life-size female figure wearing $\operatorname{a~polos}^{6}$ (fig. 1); the brow and parts of both eyebrows are preserved. There is a continuous moulded wave around the polos, possibly a snake. Traces of brown paint are visible. The head could belong to a cult statue. The other fragment is a hand holding a kylix ${ }^{7}$ (fig. 2). Large parts of the hand are monochrome. On the hand is a part of an applied snake. Both these remarkable works can be dated to the advanced Late Helladic IIIB period (13th century BC). This date is based on the shape of the kylix and the similarity of the head with the female painted plaster head of a goddess $^{8}$ and other clay cult figures from the Cult Centre at Mycenae. ${ }^{9}$ The Amyklaion fragments may well represent divinities, as is suggested by the polos and the snakes. Terracotta snake figures were found at Mycenae together with wheelmade figures of female divinities. ${ }^{10}$

The small handmade human figurines (as distinct from figures) from the Amyklaion consist of a considerable number of type Psi figurines, most of them of the late types $\mathrm{B}$ and $\mathrm{C}$ and with one or two of $\mathrm{D}$, as defined by $\mathrm{E}$. French. ${ }^{11}$ Many of them are decorated with linear or more elaborate motifs, such as wavy lines and tassels (figs 3, 4, 5). They are datable to the Late Helladic IIIB2-IIIC periods 


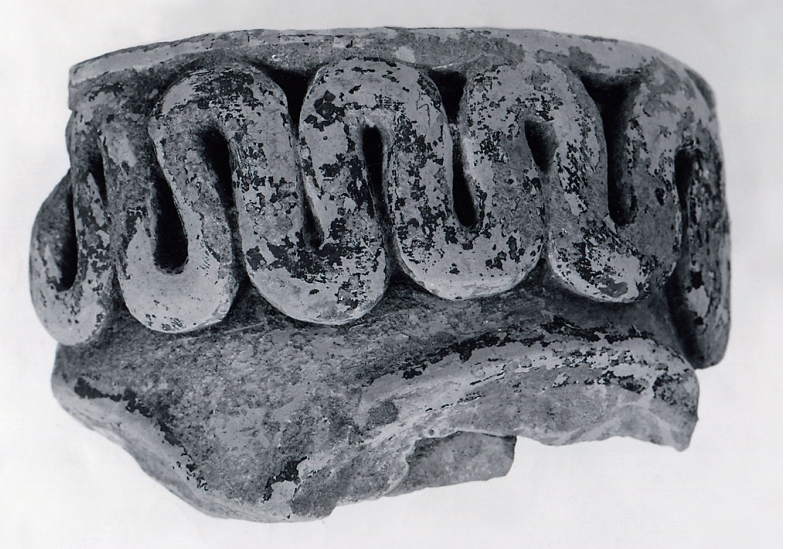

Fig. 1. Upper part of head of an almost life-size terracotta figure, from Tsountas excavations.
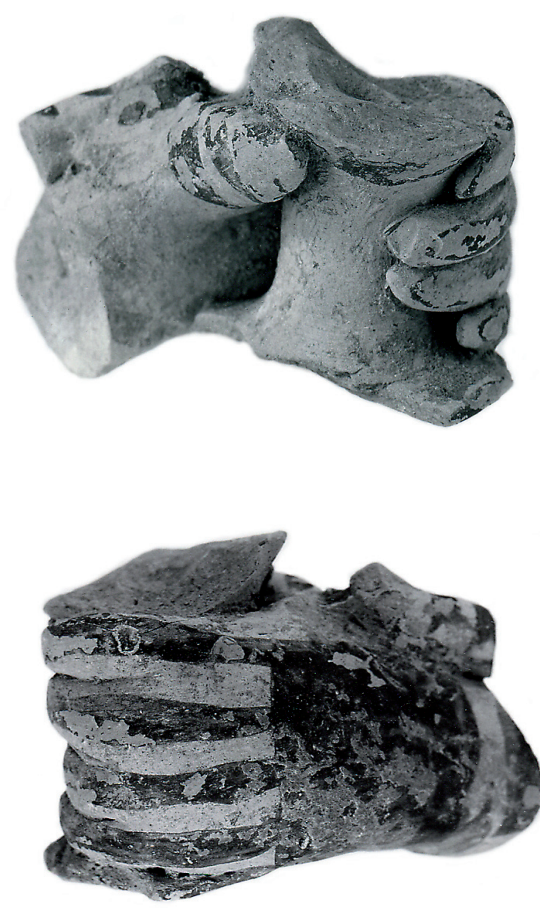

Fig. 2a-b. Hand of a large terracotta figure holding a kylix, from Tsountas excavations.

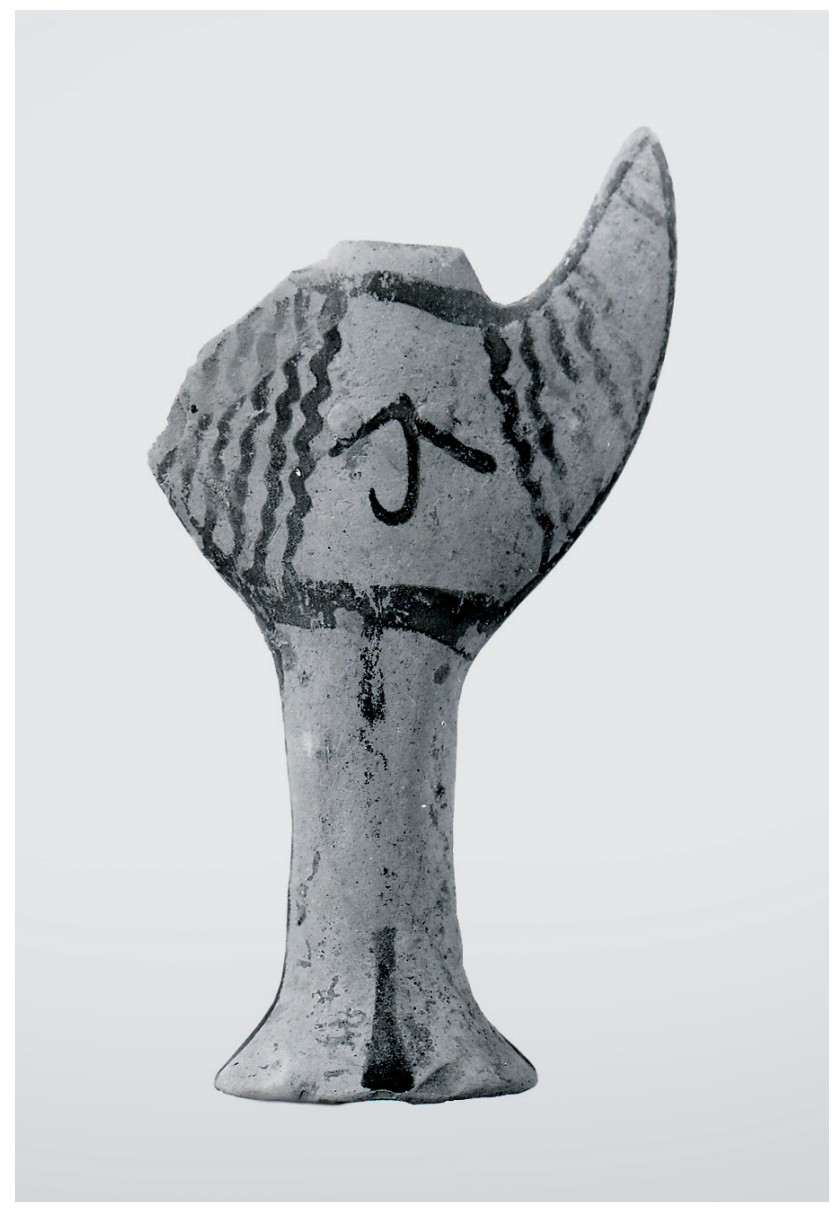

Fig. 3. Handmade figurine of type Psi with elaborate decoration, from Tsountas excavations.

(late 13th-mid 11th centuries BC) and they have affinities with the Late Psi figurines from the Syringes and the Sanctuary on the Lower Citadel of Tiryns. ${ }^{12}$ Their decoration is similar to that used for the pottery of these periods.

The group of handmade human figurines from the Amyklaion includes two horse riders, ${ }^{13}$ both fragmentary. One is a head with a pointed conical helmet, typical of rider figurines; preserved from the other is the body of the horse with part of the lower body of the rider. Figurines of horsemen have also been found in other Mycenaean sanctuaries, such as those at Methana and Epidauros (Apollo Maleatas). ${ }^{14}$

Of the four bird figurines found in the old excavations, only one is preserved. ${ }^{15}$ It is complete, handmade, with an oval body, rounded tail and open narrow wings with linear decoration. It is reminiscent of the bird figurine from the 

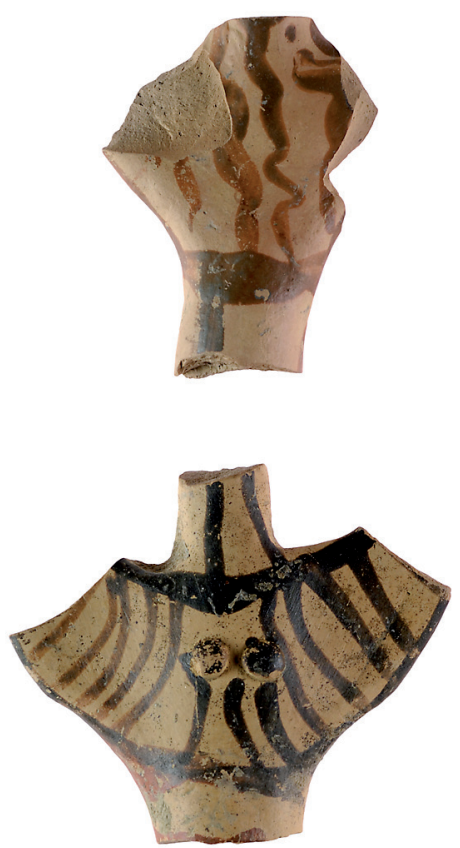
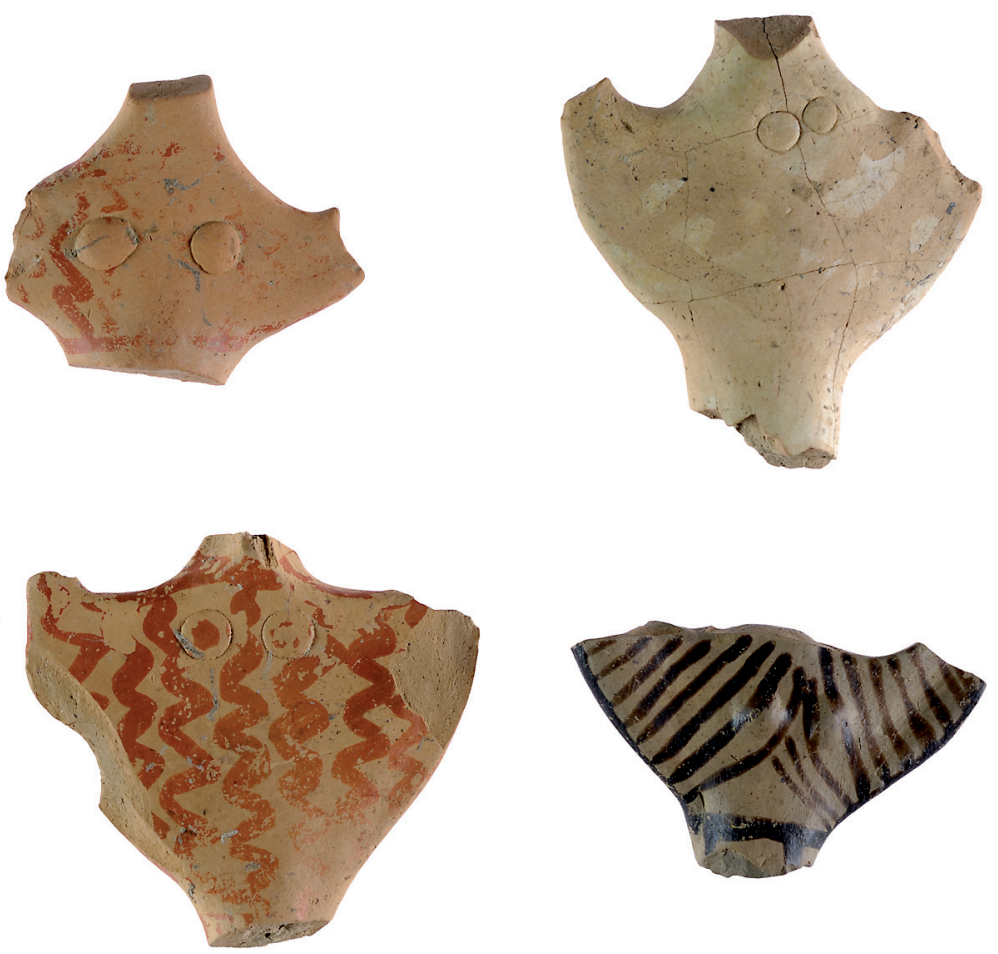

Fig. 4. Fragmentary handmade figurines of type Psi, from the recent excavations.
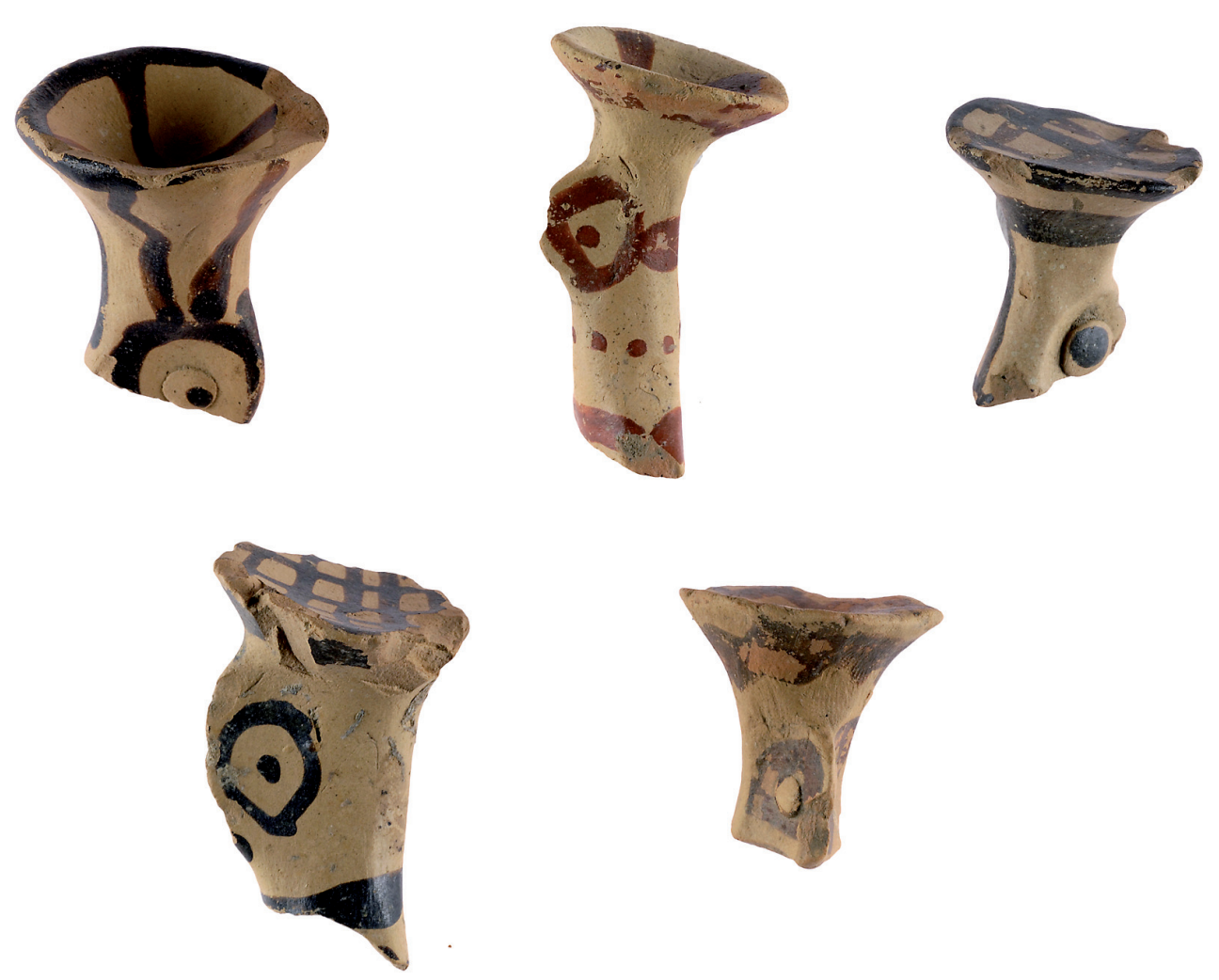

Fig. 5. Polos heads of type Psi figurines, from the recent excavations. 


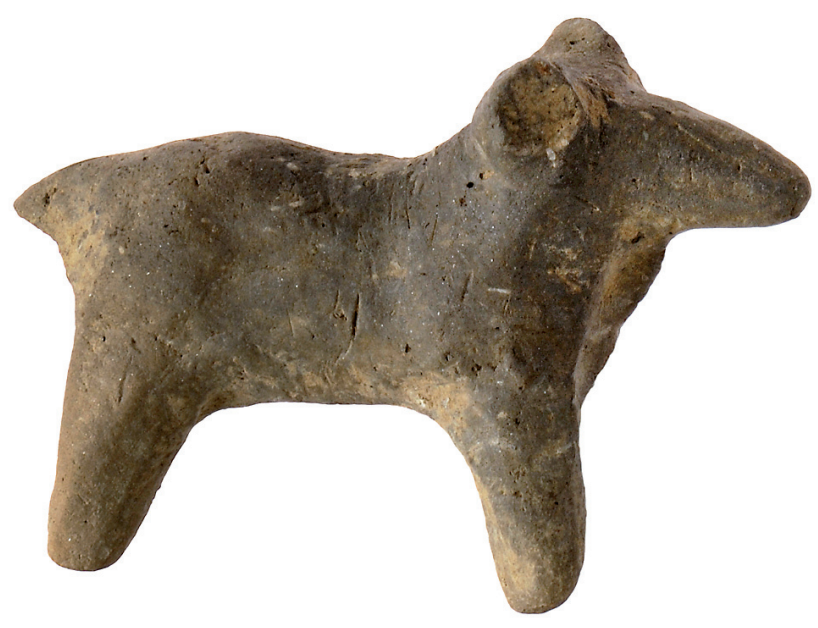

Fig. 6. Handmade plain quadruped figurine, from the recent excavations.

sanctuary of House $\mathrm{G}$ at Asine ${ }^{16}$ and can likewise be dated to the late 12th century BC. Bird figurines are less common than the animal figurines. The bird, however, is a frequent motif in Creto-Mycenaean iconography (on pottery, seal stones, wall paintings) and often has a religious significance, symbolizing the epiphany of a divinity.

The group of small handmade animal figurines is plentiful. They represent various quadrupeds, such as bovids, horses, dogs, pigs, sheep and goats. ${ }^{17}$ Some have a linear decoration, while others are monochrome or plain (fig. 6). They are dated to the Late Helladic IIIB2-IIIC periods (late 13th-mid 11th centuries BC), like the handmade human figurines. They can be paralleled with the handmade animal figurines from the Syringes of Tiryns. ${ }^{18}$

Most important are the large wheelmade animal figures. ${ }^{19}$ Most of them are fragmentary, but their height can be estimated from 0.25 to $0.30 \mathrm{~m}$. About thirty represent bovids or bulls and two are horses. The figures of this type, which originated in Minoan prototypes, are not as common as the small handmade human and animal figurines of mass production. Their body is hollow, barrel-shaped, while their head and feet are either solid or hollow. They usually have a linear decoration, but there are quite a few with elaborate patterns.

Some of the wheelmade bovid figures from the Amyklaion are finely decorated. ${ }^{20}$ There is an almost whole bull figure (fig. 7) and some fragments from other bovids, which are richly decorated with typical motifs of the Late Helladic IIIC Middle phase (mid-12th century $\mathrm{BC}$ ), such as fringed semi-circles, zigzags and elaborate triangles with bird heads. There is also a bull fragment decorated in the Close Style with rosettes and triangular patch, reminiscent of another bovid figure with rosettes from the Syringes of Tiryns. ${ }^{21}$ It is noteworthy that these elaborate motifs were used not only for the decoration of vases, but also for terracotta figures.

A number of pieces of wheelmade bovine figures, such as some solid heads and various body fragments might belong to a later phase, the Late Helladic IIIC Late phase or even to Submycenaean (11th century BC). This is suggested by their darkground decoration, including typical designs of these periods, such as isolated semicircles with fringe and vertical wiggly lines. ${ }^{22}$ Noteworthy is a solid, plain head with applied eyes of a large bovine figure (fig. 8). Of considerable interest is a large part of the rear of the hollow body of a bull figure showing also the genitals, which are applied. ${ }^{23}$ It is darkground with a reserved zone bearing zigzags on a double line. This decoration suggests Submycenaean as a date. To the same period belong two more bovine figures, one partly restored from fragments ${ }^{24}$ (fig. 9). Their decoration of large isolated semicircles, chevrons with fringe, net and wiggly fine lines resembles the motifs on Submycenaean vases. Furthermore, the short barrel-like body of both figures and their decoration are reminiscent of the wheelmade Protogeometric stag from Kerameikos, which, as has been suggested, has artistic affinities with Mycenaean animal figures. ${ }^{25}$

In addition to the terracotta figures and figurines, fragmentary pottery was found, comprising some sherds of plain vases, mostly kylikes, of the Late Helladic IIIB2 period and fragments of open vases of Late Helladic IIIC. Noteworthy is the fragment of a deep bowl decorated in the Close Style. ${ }^{26}$ The fine decoration, which recalls that on Close Style deep bowls from Mycenae, as well as the good fabric suggest that the original vase could have been imported from the Argolid. There are also fragments from ring-based kraters; one has a pictorial decoration with a battle scene. ${ }^{27}$ The pottery of Late Helladic IIIC Late/Submycenaean includes some kylix stems, ribbed or with linear decoration. ${ }^{28}$ This category of kylikes is known from other sites, notably in West Greece. ${ }^{29}$

After the description and analysis of the finds from the old and recent excavations at Amyklae, we may come to some conclusions. The Mycenaean sanctuary was estab- 


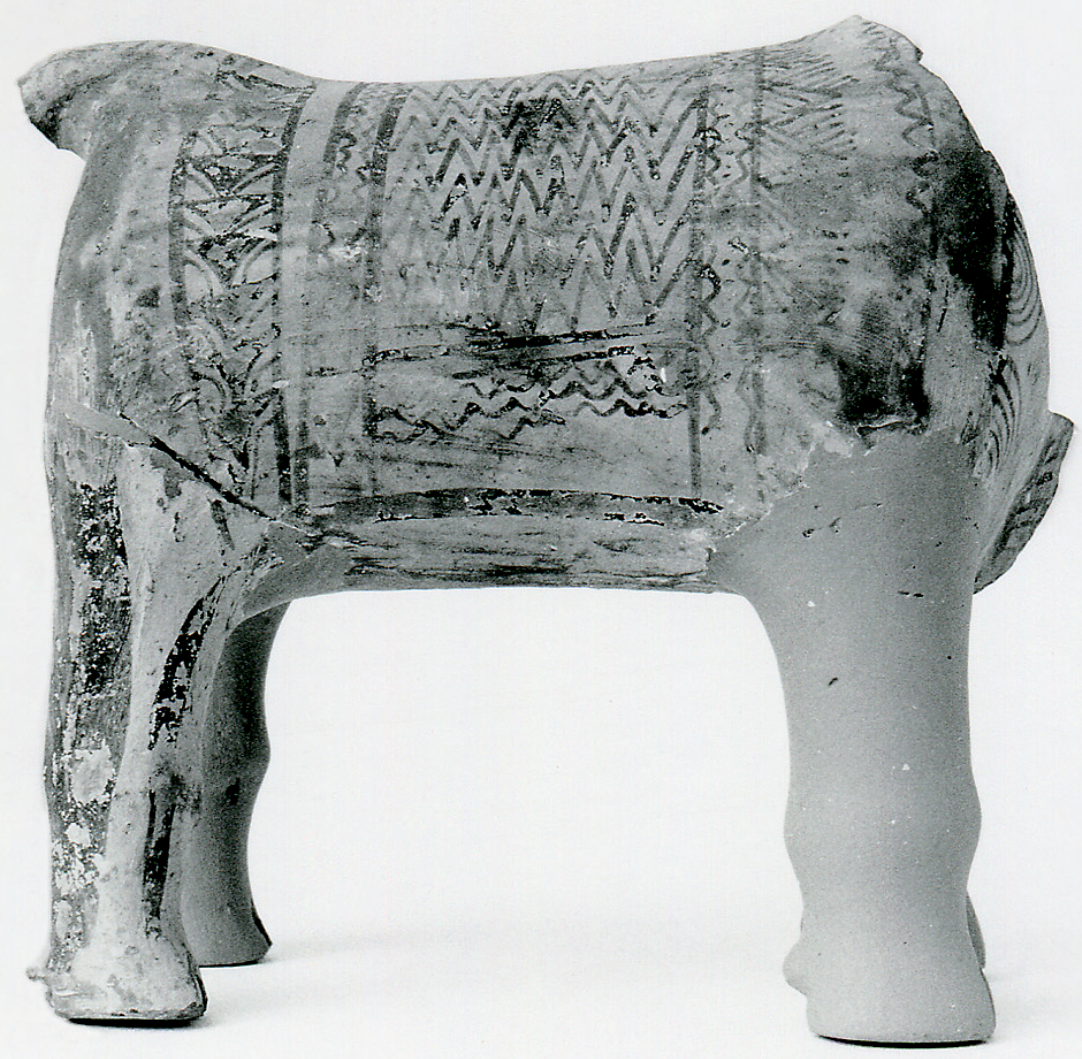

Fig. 7. Wheelmade bull figure with elaborate decoration, from Tsountas excavations.

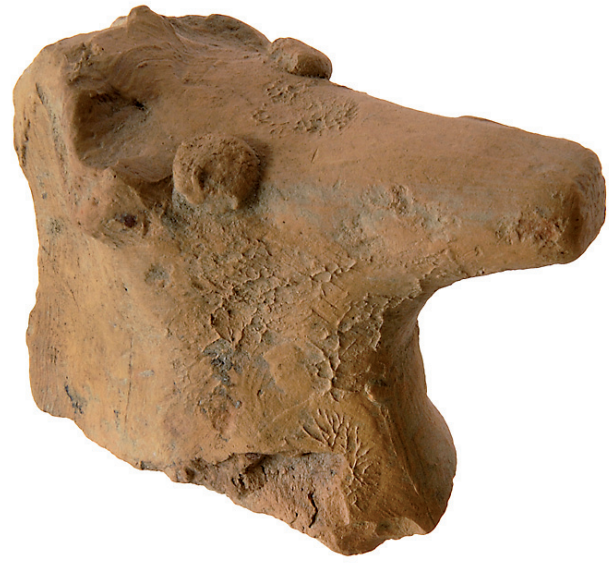

Fig. 8. Solid plain head of a large bovine figure, from the recent excavations. lished in Late Helladic IIIB2 (second half of 13th century $\mathrm{BC})$, a little before the demise of the palatial centres in the Mainland, and continued to prosper during the Postpalatial period throughout the entire Late Helladic IIIC and Submycenaean periods, until some time in the second half of the 11th century BC. Evidence for religious activity is attested by the large number of terracotta human and animal figures and figurines, especially by the two human figures on a much larger scale. The latter evidently served as cult figures in the sanctuary. Large human cult figures have been found in the great Mycenaean sanctuaries, at Mycenae, ${ }^{30}$ Tiryns, ${ }^{31}$ and Phylakopi on Melos. ${ }^{32}$ The large wheelmade animal figures, bovid and equid, constitute a significant group and most probably were offerings to the sanctuary from members of the upper social classes. Animal figures of this type have been found in the sanctuaries at Tiryns, ${ }^{33}$ Phylakopi, ${ }^{34}$ Kea (Agia Irini, Temple), ${ }^{35}$ Epi- 

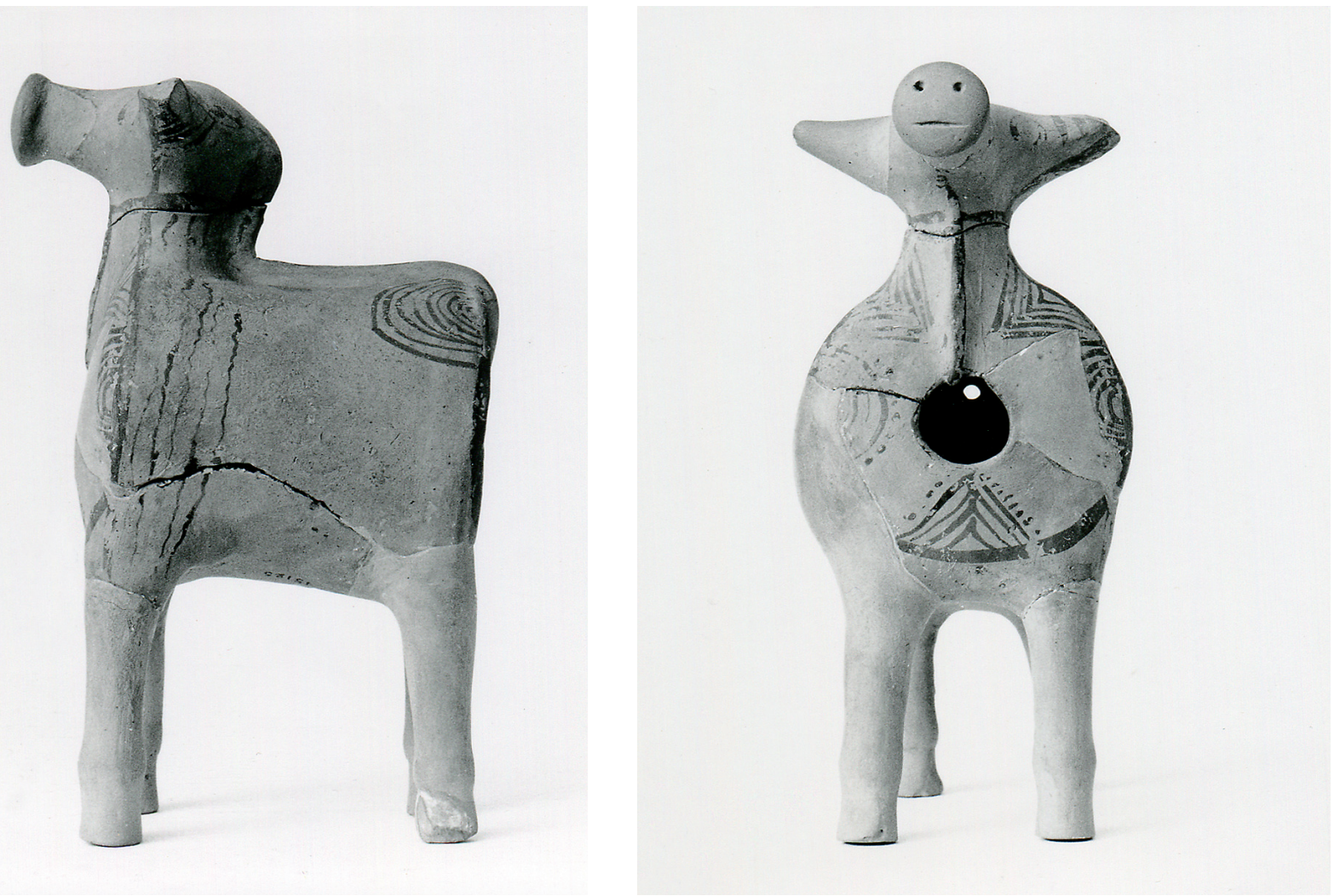

Fig. 9a-b. Wheelmade bovine figure with linear decoration, from Tsountas excavations.

dauros (Apollo Maleatas), ${ }^{36}$ Kalapodi $^{37}$ and Methana. ${ }^{38}$ The ordinary handmade animal figurines could be offerings of lower social classes, most probably from the farmers of the region. The abundance of all these figures and figurines demonstrates that the sanctuary can be included in the category of the great Mycenaean cult centres.

The structure of the sanctuary has not been preserved. It may have been destroyed by the extensive building activities for the establishment of the Archaic sanctuary. This would explain the scattering and the fragmentary condition of the finds. It has been suggested, however, that the Mycenaean sanctuary was an open-air shrine with a simple enclosure like the shrines at Epidauros and Aigina (Aphaia). ${ }^{39}$

As at other Mycenaean sanctuaries, at the Amyklaion there is the problem of its association with some centre. The absence of Mycenaean structural remains shows that this centre could not have been on the Agia Kyriaki hill. It may have been at the site recently discovered at Agios Vasileios near the Amyklaion..$^{40}$ Linear B tablets and other important finds have shown that this is indeed a major
Mycenaean administrative centre. The sanctuary that was established in the late 13th century BC could well be associated with this centre. In the Postpalatial period, however, with the collapse of the strong centres, the sanctuary might be connected as a common cult place with a group of communities in the region.

There is also the question of the continuing use of the site as a sacred place through the succeeding Early Iron Age. It is noteworthy that the deposition of terracotta animal figures in the sanctuary continued during the Submycenaean phase with a number of figures decorated with motifs typical of this style. This provides strong evidence for the existence of ritual practices at the site to the very end of the Bronze Age. The abundance of the Protogeometric and Geometric pottery indicates that cult activity continued through the succeeding Early Iron Age into Protogeometric and Early Geometric times. The offerings, however, changed. They are now chiefly bronzes: pins, spearheads and an iron sword of type $\mathrm{II},{ }^{41}$ together with some small clay drinking vessels. ${ }^{42}$ 
It was believed in the past that there was a chronological gap between the Mycenaean and the Protogeometric sanctuaries at Amyklae. Yet it is possible that the cult continued at the site without interruption until the appearance of the Protogeometric pottery. In the new sanctuary, however, a change is evident in both ritual practices and cult, most probably with the introduction of a different deity or deities. This is a matter of continuity that has occupied

\section{Notes}

* The finds of figs 1-9 were photographed by a) I. Ioannidou and L. Bartzioti (Tsountas excavations) and b) L. Kourgiantakis (recent excavations).

1. Tsountas 1892, 1-18.

2. Fiechter 1918, 107-245; Buschor - von Massow 1927, 185.

3. Demakopoulou 1982, 36-42, 80-82.

4. Demakopoulou 1982, 37, 79; Tsountas 1892, 12-16; Buschor - von Massow 1927, 33.

5. Demakopoulou 1982, 43-68.

6. Demakopoulou 1982, 54-55, pl. 25; Demakopoulou 2009b, 96, fig. 10.1 .

7. Demakopoulou 1982, 55-56, pl. 26; Demakopoulou 2009b, 97, fig.10.2a-b.

8. Tsountas 1902, 1-10, pls 1-2.

9. Moore - Taylour 1999, 46-47, pl. 12.

10. Moore - Taylour 1999, 63-66, pls 23-25.

11. French 1971, 139-40, pls 21-22: a-d; Demakopoulou 1982, 44-50, pls 2-24; Demakopoulou 2009b, 97-98, figs $10.3-4$.

12. Weber-Hiden 1990, 45-53, pls 37-40.

13. Demakopoulou 1982, 53-54, pl. 24: 65a, 66.

14. Konsolaki-Yannopoulou 1999, 227-33, pls 54-55.

15. Demakopoulou 1982, 66-67, pl. 49.

16. Frödin-Persson 1938, 310, fig. 213.

17. Demakopoulou 1982, 63-66, pls 40-48.

18. Weber-Hiden 1990, 57-76, pls 41-47.

19. Demakopoulou 1982, 57-63, pls 27-39; Guggisberg 1996, 54-60, pls 10-12; Demakopoulou 2009b, 98-100, figs $10.5-11$.

20. Demakopoulou 2007, 165.

21. Demakopoulou 1982, 59, pl. 34:79; Weber-Hiden 1990, scholars extensively over time. ${ }^{43}$ It is indeed unfortunate for research on the chronological sequence of the sanctuaries that the Mycenaean figures and figurines retrieved from the old and the recent excavations did not come from stratified deposits.

Katie Demakopoulou

k.demakopoulou@gmail.com
82, no. 169 , pl. 51:169.

22. Demakopoulou 2009a, 120-21, figs 15-22.

23. Demakopoulou 2009a, 120, fig. 18.

24. Demakopoulou 2009a, 120-21, figs 19-22.

25. Nicholls 1970, 13, 15, pl. 2c; Snodgrass 1971, 401, fig. 119; Guggisberg 1996, 72, no. 221, pl. 15:9.

26. Demakopoulou 1982, 68, pl. 51:119.

27. Demakopoulou 1982, 69-70, pl. 50:116.

28. Demakopoulou 1982, 71-72, pl. 52; Demakopoulou 2009a, 121.

29. Eder 2006, 141-246.

30. Moore - Taylour 1999, 46-50, pls 11-12.

31. Kilian 1978, 461-65, figs 17, 20-21, 23.

32. French 1985, 209-22, pl. 31, fig. 6:3-8.

33. Kilian 1992, 21, pl. 3.

34. French 1985, 236-52, pls 32b, 39-42, fig. 6:15-24.

35. Caskey 2009, 155, fig. 20.

36. Lambrinoudakis 1981, 63, fig. 8.

37. Felsch 1999, 165-66.

38. Konsolaki 2002, 34, fig. 13.

39. Pilafidis-Williams 1998.

40. Vasilogambrou 2012, 544-47. See also Ergon 2011, 2931; Ergon 2012, 50-53.

41. Demakopoulou 1982, 73-76, 93; Desborough 1972, 241; Snodgrass 1971, 245-46, fig. 88; Calligas 1992, 41-42.

42. Demakopoulou 2009b, 103; Dickinson 2006, 232.

43. For these topics, see among others Nicholls 1970, 10; Desborough 1972, 240-41, 280; Demakopoulou 1982, 90 96; Demakopoulou 2009a, 123; Wright 1994, 65; Eder 1998, 99-100, 136-37; Morgan 1999, 371, 382-84, 390; Dickinson 2006, 232. 


\section{КАІTН $\triangle$ НМАКОПОҮ ОУ}

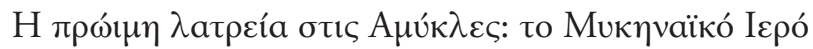

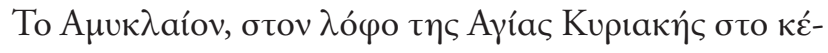

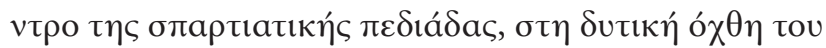

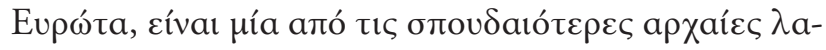

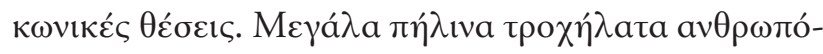

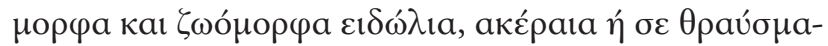

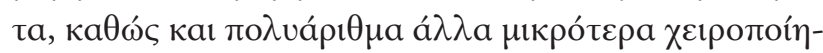

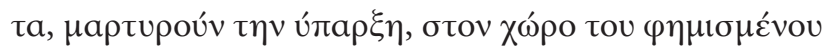

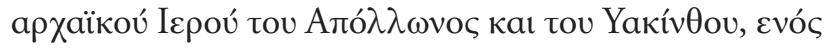

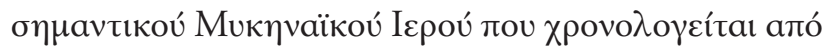

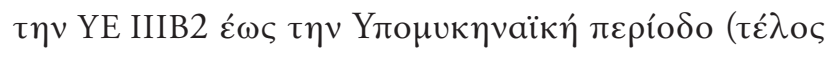

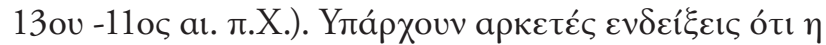

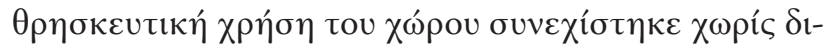

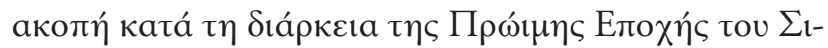

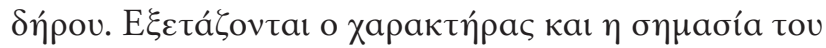

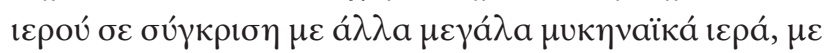
ava

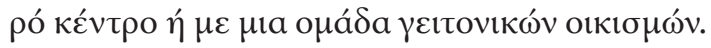

